\title{
The Spleen of a Specialy Adapted Mammal: The Little Hairy Armadillo Chaetophractus vellerosus, (Xenarthra, Dasypodidae). A Light and Electron Microscopic Study
}

\author{
El Bazo de un Mamífero con Adaptaciones Especiales: el "Peludo Chico" Chaetophractus vellerosus, \\ (Xenarthra, Dasypodidae). Estudio con Microscopía de Luz y Electrónica \\ "Elena Juana Galíndez; "Silvia Estecondo \& **Emma B. Casanave
}

GALÍNDEZ, E. J.; ESTECONDO, S. \& CASANAVE, E. B. The spleen of a specialy adapted mammal: The little hairy armadillo Chaetophractus vellerosus, (Xenarthra, Dasypodidae). A Light and electron microscopic study. Int. J. Morphol., 24(3):339-348, 2006.

SUMMARY: The spleen is a multifunctional organ. Its microarchitecture reflects so well the phylogeny as the adaptation to niche in each animal group and inclusive in each species.

Armadillos, as ancient and isolated mammals, show a mixture of ancestral and modern structures. In this work the microanatomy and cytology of the spleen of the little hairy armadillo Chaetophractus vellerosus was studied. The material was fixed and processed according to the typical methods for light and electron microscopy.

Results show a cumulative medium sized spleen with the typical pulps. The white pulp is well developed but less defined than in other armadillos. The presence of follicular-dendritic-like cells and interdigitant dendritic-like cells, as well as clusters of immunocompetent cells agrees with an active immunological activity. The red pulp is a meshwork of circulatory spaces and cells. The presence of splenic sinusoids is recognized for the first time in the genus. Hemopoietic tissue is less developed than in other Euphractini. The microarchitecture and size of the spleen of $C$. vellerosus is discussed in a phylogenetic and adaptive context.

KEY WORDS: Xenarthra; Dasypodidae; Armadillos; Spleen; Chaetophractus vellerosus.

\section{INTRODUCTION}

The spleen is an important organ centrally interposed in the systemic circulation related with the immune, haemocatheretic, flow regulation and myeloid functions. Since their appearance, included in the gut of Agnatha and as an extramural structure from chondrichthyes (Zapata et. al., 1995), it proportionally mixed these functions, according to their architecture and the needs of each animal form.

In the beginning, the spleen was a myeloid organ with some immune functions, but at the same time as the different groups appeared and radiated, the microanatomy was remodelled and the immune, myeloid, haemocatheretic and flow regulation functions take different relative importance (Galíndez \& Aggio, 1997). Mammals are a good example. In Prototheria, the spleen is mainly a myeloid organ with a scarce immunological importance (Tanaka et al., 1988). In Metatheria (Cisternas \& Armati, 1999) and Eutheria (Hartwig \& Hartwig, 1985) the splenic structure is similar. The ancestral group Insectivora shows an important splenic myeloid activity (Tanaka, 1994); meanwhile the great diversity of mammal's orders shows an extensive spectrum in each function, according to phylogeny and/or adaptation (Hartwig \& Hartwig).

The armadillos are an ancient eutheria group appeared in the limit between the Cretacic and the Tertiary, that has been isolated since their origins to the beginning of the Eocene (Delsuc et al., 2001). They are semifossorial animals with an unusual response to $\mathrm{CO}_{2}$ increase (Boggs et al., 1998). Moreover, this group has generated interest because their importance as biomedical models in various human and

\footnotetext{
* Lab. Histología Animal, *Lab. Fisiología Animal, Universidad Nacional del Sur, Dpto. Biología, Bioquímica y Farmacia, Bahía Blanca, Argentina.

*** Miembro de la Carrera de Investigador del CONICET (Consejo Nacional de Investigaciones Científicas y Técnicas), Argentina.

Trabajo subsidiado por SGCyT, UNS 24 B086 y 24B122; y ANPCyT, BID 1728 OC-AR, PICTR 074/03.
} 
animal illness (Scollard, 2000); Cheadle et al., 2001; Fernandes et al., 2004) and they are known as vector of parasites for another mammals including man (Silva Vergara \& Martínez, 1999).

In spite of these remarks, the morphology, physiology, ecology and conservational status of the group are poorly known and only some work exists about genus Chaetophractus (Casanave \& Affanni, 1995; Casanave \& Polini, 1999; Estecondo \& Casanave, 1999; Polini et al., 1999; Codón et al., 2001; Maldonado et al., 2002, Bermúdez et al., 2004; Casanave et al., 2005, 2006). The little hairy armadillo $C$. vellerosus shows a physiological adaptation to semiarid environments (Greegor, 1975) but only some studies about this species have been published (Greegor, 1980; Estecondo et al., 1997; 2001). In this work, we analyse the spleen's microanatomy, histology and cytology of $C$. vellerosus from the Bahía Blanca Region.

\section{MATERIAL AND METHOD}

Five clinically healthy adult specimens of $C$. vellerosus, weighing between 1000 and $1340 \mathrm{~g}$ were caught during autumn and winter with traps in the Bahía Blanca Region (SE of the Buenos Aires Province, Argentina), and transported alive to the special armadillo's installations of the animal house. They were located in individual cages where they remained in process of adaptation for, at least, one month. Twenty-four hours before the dissection, the supply of food was retired. Previously to the induction of the anaesthesia, the animals were soothed with promazine maleato $(1 \mathrm{mgr} / \mathrm{kg})$ and then we proceeded to kill them with an overdose of intraperitoneal sodium thiopental (Pentothal ${ }^{\circledR}, 75 \mathrm{mg} / \mathrm{kg}$ ). The death by overdose of anaesthesia may be associated with the accumulation of blood in the spleen, essentially by the hypotensor effect of the drug (Hardman et al., 1996). To avoid this inconvenience, immediately after the separation of the organ, we drained the excess of blood pressing smoothly with gauze. The spleen was immediately weighted and perfused, through the lienal artery, with Bouin fixative for optic microscopy. Thin sections of paraffin embedded pieces (4-6 $\mu \mathrm{m})$ were prepared and stained with hematoxylin-eosin, Masson's trichromic stain, Periodic Acid Shiff (PAS) reaction and Perls reaction for iron deposits.

For electron microscopy, small pieces of unfixed tissue were immersed in $2.5 \%$ glutaraldehyde in $0.1 \mathrm{M}$ cacodylate buffer at $4^{\circ} \mathrm{C}$ for 12 hours, and then post fixed in $1 \%$ osmium tetroxide in the same buffer for 90 minutes at $4^{\circ} \mathrm{C}$. They were then dehydrated in graded acetone and infiltrated in low-density resin (Spurr). Semithin sections were coloured with a metilene blue, azure II and basic fuchsin technique. The ultra-thin sections on grids were contrasted with uranyl acetate and lead citrate. Specimens were examined in an electron transmission Jeol 100 CXII, Tokyo, Japan, microscope.

Material for scanning was fixed as described above, dehydrated in graded acetone, broken into small pieces in liquid nitrogen, dried by critical point, coated with gold by the ion-sputtering method and observed in a Jeol JSM-35CF scanning electron microscope at $0.5 \mathrm{KeV}$.

All follicles and transitional zone in any one of three consecutive slides from each animal were measured with a micrometric ocular. Two morphometric ratios were calculated: one of them is the relation between minimal and highest values for follicle diameters and the other is the ratio between the transitional zone width and the average of follicle diameters. The first ratio is considered a measure of the "regularity of the form" and the second deals with the relation of intermediate zone with the nodule size.

\section{RESULTS}

The dorsal and trilobated spleen of $C$. vellerosus is medium sized (Table I). The spleen weight/body weight ratio average represents the $0.502 \%(\mathrm{SD}=0.104, \mathrm{n}=5)$.

Table I. Morphometric data of animals.

\begin{tabular}{|c|c|c|}
\hline Body weight (g) & Spleen weight $(\mathrm{g})$ & Spleen/body x 100 \\
\hline 1080 & 3.30 & 0.308 \\
\hline 1340 & 5.29 & 0.395 \\
\hline 1050 & 7.31 & 0.692 \\
\hline 1000 & 3.11 & 0.311 \\
\hline 1215 & 9.76 & 0.803 \\
\hline
\end{tabular}

Many parallel branches of the lienal artery run to the longitudinal axis and penetrate the parenchyma.

This organ is covered by a thin $(30-60 \mu \mathrm{m})$ bilayered capsule. The inner part of the capsule is mostly muscular and extends fibro muscular vascular trabeculae inside the organ stroma (Fig. 1).

The splenic pulp classically segregate into a white and a red pulps. 


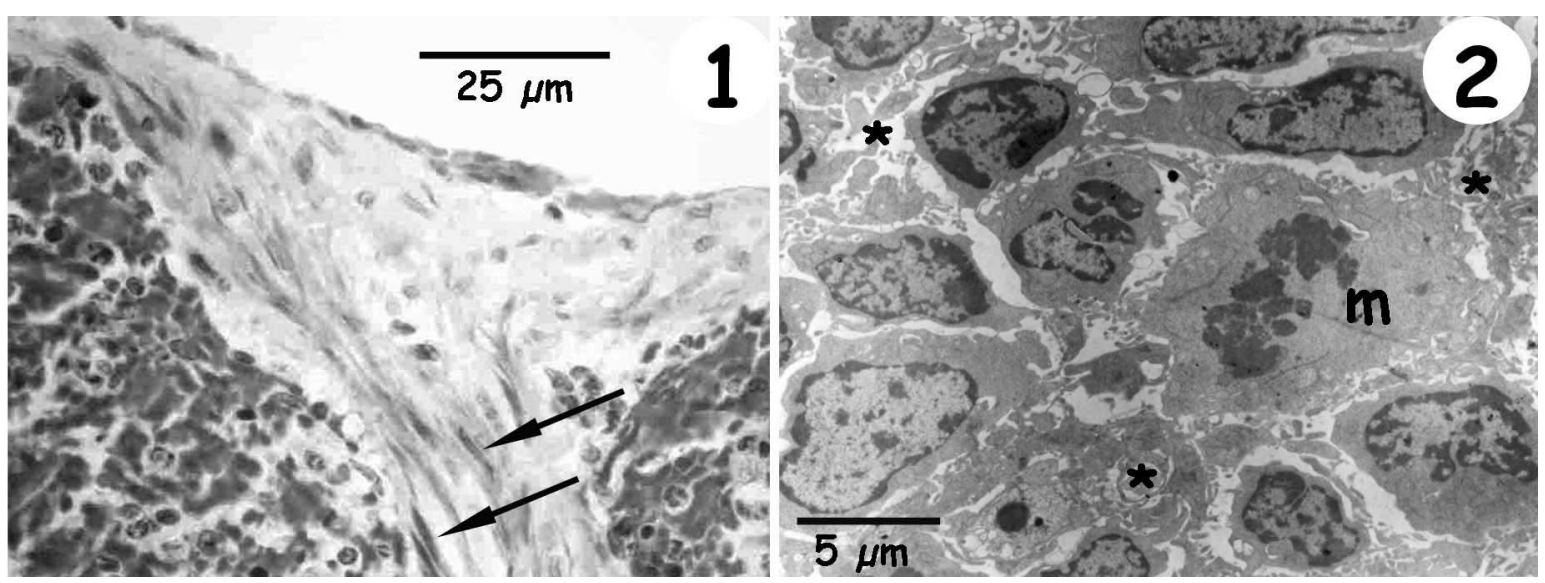

Fig. 1. Low power image of the capsule and an emerging trabeculae. Arrows indicate the nucleus of smooth muscular cells.

Fig. 2. Germinative centre of a follicle. Asterisks indicate the cytoplasmic processes of follicular dendritic-like cells. m: mitosis in a blast cell.

Nodules, periarterial sheets and ellipsoids represent the immunocompetent tissue. Nodules are very homogeneous rounded structures. The average between ratios is $0.89, \mathrm{SD}$ $=0.08, \mathrm{CV}=8.5 \%$ (Fig. a). Their germinative centres are lightly coloured with conventional techniques and moderately PAS (+). With electron microscopy, this zone is occupied by active dividing cells and a collection of supporting cells, morphologically similar to follicular dendritic cells (Fig. 2). These cells are immersed in a mass of extracellular fibrillar and amorphous material and show an euchromatic nucleus with patches of chromatin associated with the inner layer of the cariothec (Fig. 3). Sometimes the follicular dendritic-like cells show evidence of phagocytosis. A network of typical reticular cells and their fibrillar processes divide the centre from a thin mantle (Fig. 4). The eccentric arteriole shows a very thick basal membrane.

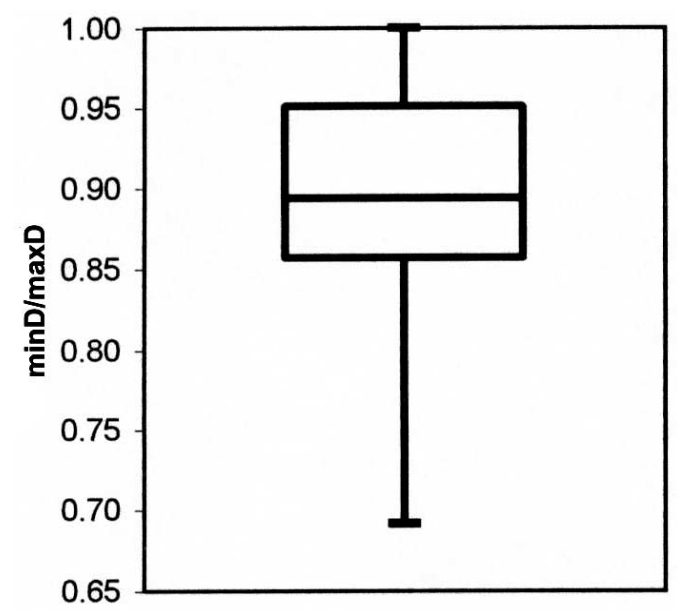

Fig. a. Box plot of relation between minimal and highest values for follicle diameters $(n=36)$.
Between pulps, there are an intermediate zone, a fibrillar and vascular network. The Perls reaction shows positive macrophages in this zone (Fig. 5). This region

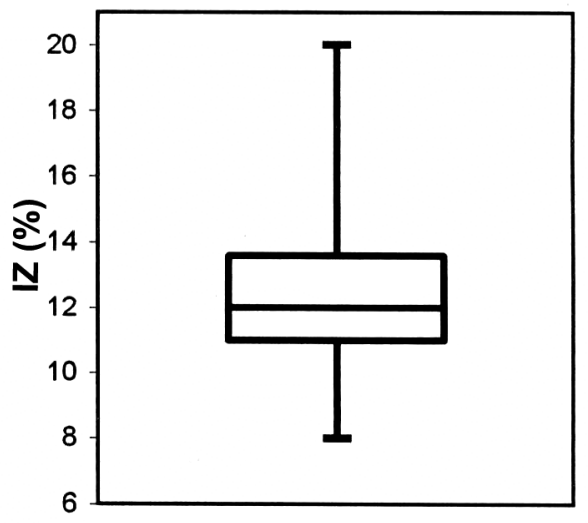

Fig. b. Box plot of ratio between the intermediate zone (IZ) width and the average of follicle diameters (in percent).

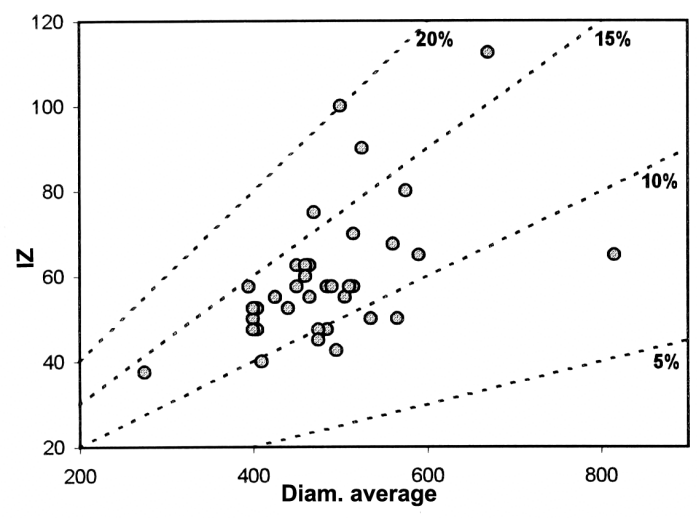

Fig. c. Regression graphic between the IZ and the relation between minimal and highest values. 
represents, in average, the $12.36 \%(\mathrm{SD}=2.52, \mathrm{CV}=20.4 \%)$ of the nodule size (Fig. b). The regression analysis between the intermediate zone width and the relation between minimal and highest values for follicle diameters is significant $(\mathrm{r}=$
0.52 , p $<0.05$, Fig. c). The narrow border of the intermediate zone shows a grading population of cells. The relationships between dendritic-like cells and lymphocytes are common (Fig. 6) as well as plasmocytes clusters.

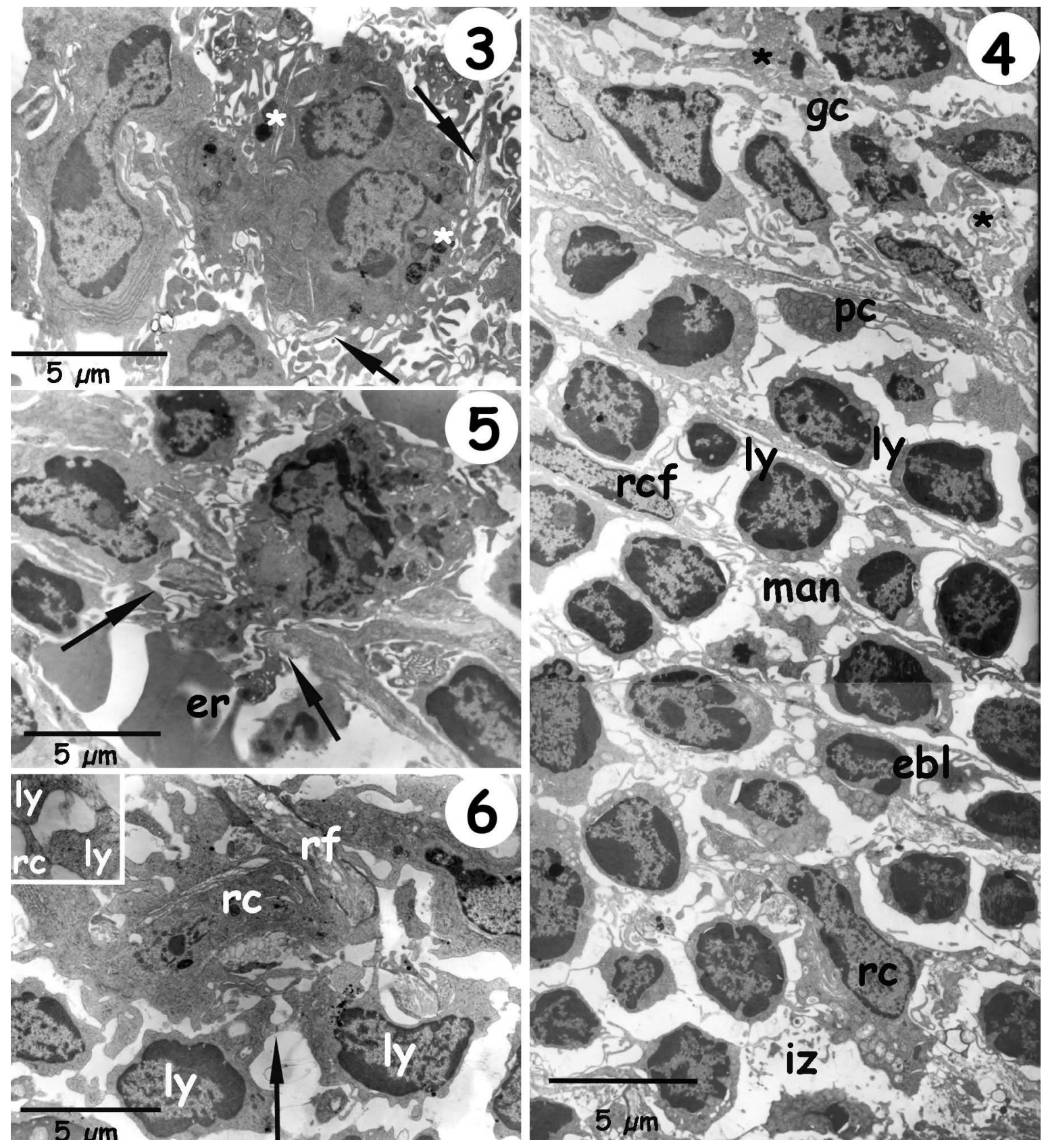

Fig. 3. Follicular dendritic-like cell with evidence of phagocytosis (asterisks). Note the large amount of cytoplasmatic processes and the extracellular fibrillar and amorphous material trapped between the processes (arrows).

Fig. 4. General TEM image across a nodule. gc: germinative centre; man: mantle; iz: intermediate zone, rc: reticular cell; pc: cytoplasm of a plasmocyte; ly: lymphocyte; rcf: reticular-fibroblastic cells; ebl: erythroblast. Arrows indicate lining fibres.

Fig. 5. Macrophage interposed between the epithelial cells of a vessel. Arrows indicate the disjoined basal membrane. er: erythocyte trapped for the macrophage.

Fig. 6. Intermediate zone. Close relationship between a reticular cell and lymphocytes. The insert image is a magnification of the zone depicted by the arrow. rc: reticular cell; ly: lymphocyte; rf: reticular fibers. 


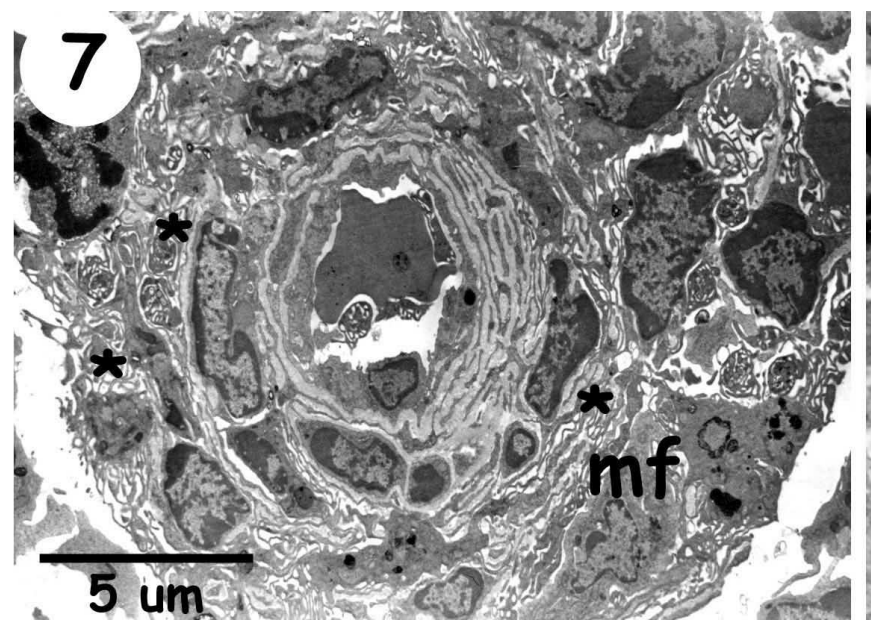

Fig. 7. Low power TEM image of an ellipsoid. Note the large amount of cytoplasmic processes of interdigitant-like cells (asterisks) and the thick and numerous sheaths of basal membrane. mf: macrophage.

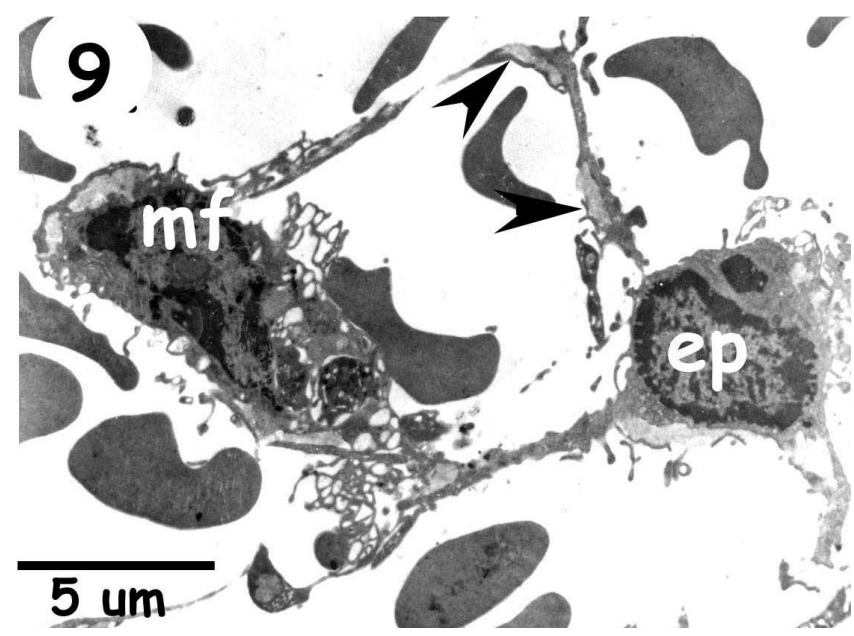

Fig. 9. Red pulp. Very small vessel defined by one epithelial cell and one reticular cell. ep: epithelial cell; mf: macrophage. Arrow indicates de basal membrane.

Ellipsoids are small and preferably located in the intermediate zone. They are organised as a central capillary surrounded by two or three envelopes of macrophages Perls $(+)$ and cells morphologically similar to interdigitant cells (Fig. 7). In these cells, the euchromatic nucleus is central and the cytoplasm sends a great number of long and arborescent projections. These finger-like projections are convolute and surround packages of fibres, as well as a kind of cells as plasmocytes, lymphocytes and developing red cells. There are not a vascular sinus around them, but is possible to find isolated interdigitant-like cells (Fig. 8).

The red pulp represent more than the $60 \%$ of the stroma and comprise different types of filtrant beds and a collection of free immunocompetent, reticular and myeloid cells. No isolated muscular cells were found. Terminal vessels may be

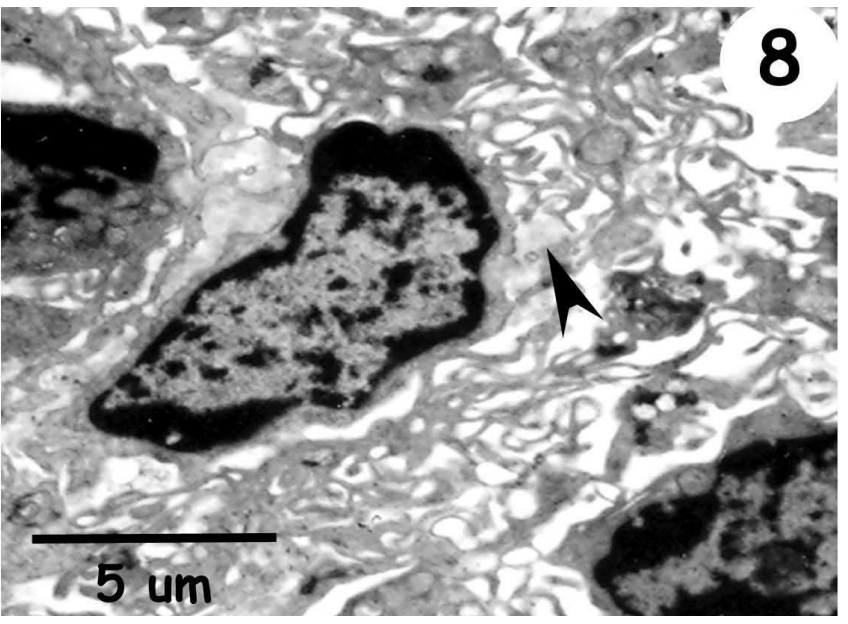

Fig. 8. Isolated interdigitant-like cell. Arrowhead indicate fibers and extracellular matrix trapped between the projections.

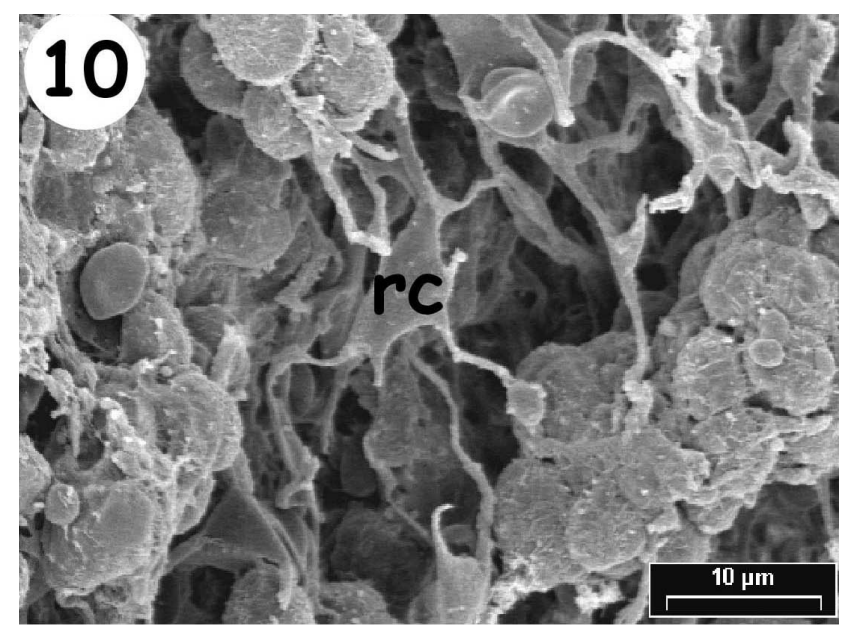

Fig. 10. SEM image of the cellular reticulum of the red pulp. rc: reticular cell.

lined by reticular cells (Figs. 9 and 10) and/or phagocytic cells or may be of the sinusoidal type. Discontinuous beds show a typical flat epithelium with a moderate thick basal membrane, opened only when there are cell transit. Sinusoidal vessels have a rounded endothelium with microvesicles in the cytoplasm (Fig. 11), somewhat in the luminal face as well in the basal face. The basal membrane clear depicts their specific "banded" structure (Fig. 11). Arterial capillaries are typical with a continuous basal membrane (Fig. 12), and associated with reticular cells and macrophages.

Myeloid tissues are poorly represented. Only madurative-proliferative stages of the erythrocytic line are common. Megakariocytes and myelocytes (Fig. 13) were found in a few number. Developing red cells show clusters of mitochondria (Fig. 14). 


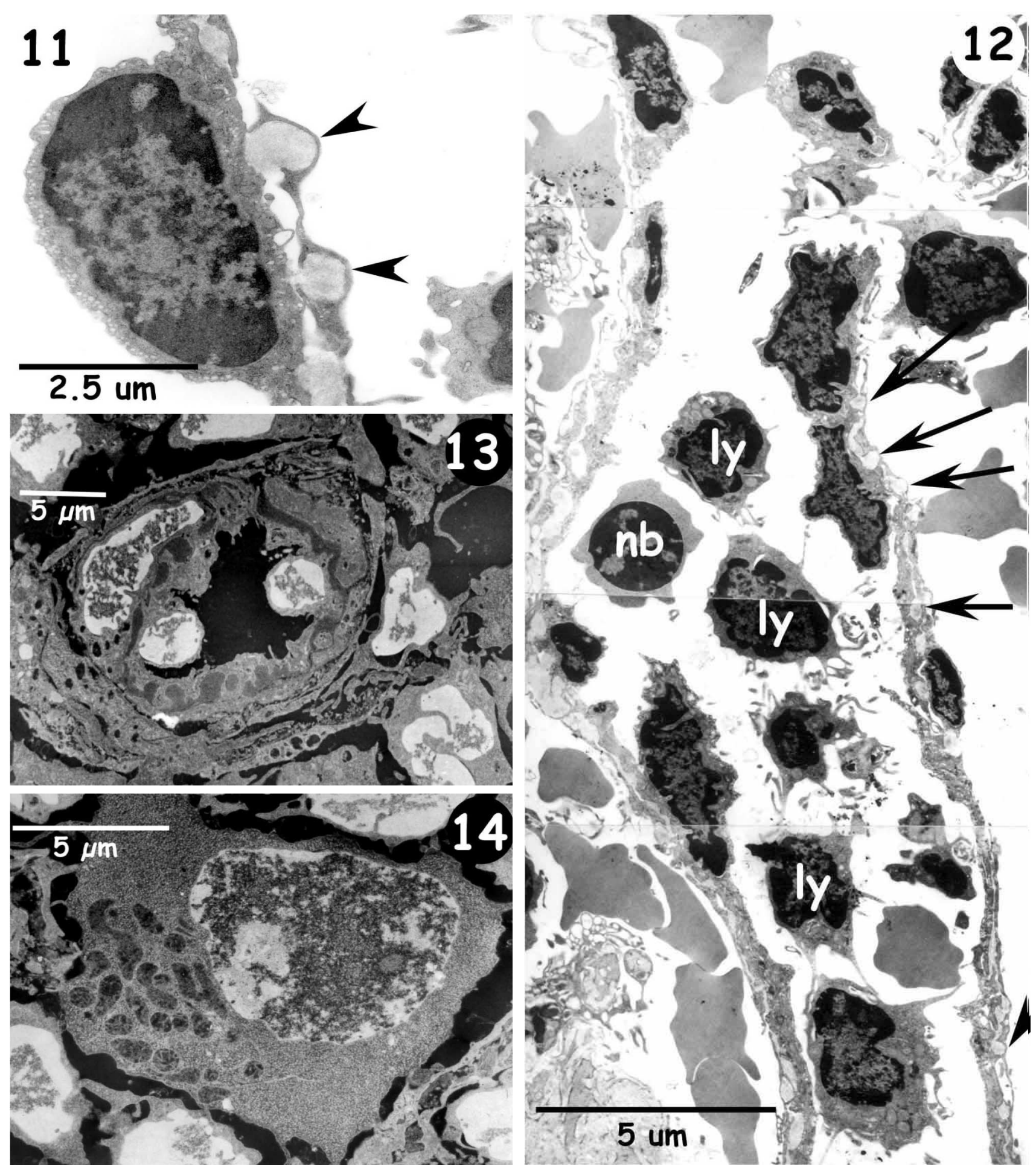

Fig. 11. High power TEM image of an sinusoidal epithelial cell with the specific basal membrane.

Fig. 12. Low power TEM image of an splenic sinusoid. Arrows indicate the typical "banded" basal membrane disposition. nb: normoblast; ly: lymphocyte (arrowheads).

Fig. 13. Arterial capillary of the red pulp.

Fig. 14. Basophile erythroblast. Note the typical cluster of mitochondria. 


\section{DISCUSSION}

The little hairy armadillo has, in Bahía Blanca $\left(38^{\circ}\right.$ $45^{\prime} \mathrm{S}: 62^{\circ} 30^{\prime} \mathrm{W}$ ) and his influence region, the most southern geographical location (personal observation - hunting zone). Carlini \& Vizcaíno (1987) report the southern limit of the species at $35^{\circ} 55^{\prime} \mathrm{S}$ : $57^{\circ} 30^{\prime} \mathrm{W}$. For this reason, this work contributes to extend the distribution of $C$. vellerosus. The Bahía Blanca region has an important agricultural productive activity and the holes that this fossorial species dig, are the principal reason why farmers hunt them and, in spite of their position as "low care" by the "Red Book" (Díaz \& Ojeda, 2000), in some restricted areas the subjective observations seem to indicate that they has decreased.

The spleen of $C$. vellerosus is normally located. The size of the organ is similar to the one of other member of the genus, C. villosus (Galíndez et al., 1997) and greater than the one of the other studied Euphractini, Z.pichiy (Galíndez et al., 2003). Nevertheless, because of the scarce number of studied exemplars, the morphometric data are offered only with informative purpose. However, the low spleen size in comparison with that from another mammals exposed to low levels of $\mathrm{O}_{2}$ and an increase of $\mathrm{CO}_{2}$, as seals and whales (Cabanac et al., 1999), induce to believe that in this armadillo there's no a clear relationship between their ecological niche and the volumetric capacity of the spleen. Moreover, the hypoxic environment of burrows is perhaps compensated by the spleen, but due to the low metabolic rate of armadillos (Boily, 2002) and their special response to low $\mathrm{O}_{2}$ levels (Casanave \& Affanni; Casanave et al. 1995), probably it is not necessary a large organ.

The presence of muscular tissue in the capsulotrabecular system and the extensive system of vascular beds of the red pulp indicates a "cumulative type spleen" or a "Type III" spleen (Hartwig \& Hartwig). This fact agrees with the splenic structure observed in D. novemcinctus (Hayes, 1970) and D. hybridus (Galíndez et al., 2000) and differs from the observed in Z. pichiy, which shows isolated smooth muscle cells and myofibroblasts interposed between filtrant beds (Galíndez et al., 2003). An indirect proof of adaptive remodelling of the splenic microarchitecture in armadillos, is the fact that new-borns of $C$. villosus, have a myeloid spleen without trabeculae (Galíndez et al., 1997).

In $C$. vellerosus, the cumulative spleen may represents an adaptation to blood storage or blood clearance rather than a reflex of the phylogenetic position of the group.

These animals are exposed by food habits and habitat to great antigenic stimulation and this may be an important stimulus for the white pulp components. In spite of this supposition, $C$. vellerosus shows a normal proportion of well-conformed nodules, sheets and ellipsoids, but the proportion of immunocompetent tissue in the stroma is different from "immunologic spleens" as in other mammals (Weiss, 1989; Aichele et al., 2003).

It is known that some cells may be conservative in the structural phenotype among evolutionary clads (Carleton, 1996). The presence in C. vellerosus of folliculardendritic-like cells still presents from fishes (Zapata \& Cooper, 1990), agrees with the conservation of structures.

The intermediate zone has narrow borders than the other studied Euphractini (Galíndez et al., 1997, 2000, 2003), and differs from rabbits and rodents (Blue \& Weiss, 1981). The presence of macrophages Perls (+), ellipsoids and a discrete amount of vasculature, make this structure very similar to that present in the ancestral group Insectivora (Tanaka, 1990) and is, probably, the place for blood clearance. The regression analysis shows a clear relationship between nodules size and the intermediate zone. This fact may be associated with an increase in the clearance function according with a concordant increase in the function.

Ellipsoids are less defined in C. vellerosus than in $C$. villosus (Galíndez et al., 1997) and differ from those of $D$. novemcinctus (Hayes, 1970). Due to the low number of macrophages in the intermediate zone and their presence in the sheath envelope, the ellipsoids are, probably, the place for the splenic clearance, as occur in cat (Blue \& Weiss).

The presence of splenic sinus in C. vellerosus is the first report for the genus. Only one other report exists for armadillos (Hayes). The sinusoids as well as fenestrate venules coexist, in this species, as occur in man (Weiss et al., 1985). The sinusoidal structure combined with the ability for a strong spleen contraction offer the possibility of a direct and rapid blood flux across the organ (Weiss, 1989). Splenic sinuses are considered "more evolved" structures. Their presence in a relictual mammal suggest that the adaptive pressure is so important as the evolutionary level in the anatomical organisation of each organ, and in this fossorial animal, may be correlated with its adaptation to the niche.

C. vellerosus shows less splenic myeloid tissue than others armadillos of the Bahía Blanca region. This fact may be related with the moment of the necropsy which was done in latter autumn and winter; considering that armadillos may 
show seasonal hemopoiesis, as reported by Weiss \& Wislocki (1956), it is possible that the low number of committeddeveloping cells was according a steady status. Nevertheless, cells from granulocytic line were not found in C. villosus or Z. pichiy, and this is the first report for them.

In brief, the splenic micro architecture of $C$. vellerosus, as well as other vertebrates, reflects so the phylogeny as the adaptation to their ecological niche (Hartwig \& Hartwig, 1985). They show a mixture of "advanced" (type III spleen) and "ancestral" characteristics (splenic hemopoiesis through the life, intermediate zone between pulps). This conjunction makes the species an interesting model for the study of the physiology and the phylogeny of the spleen, and contributes with the phylogenetic investigations of Xenarthra, the group to which it belong.

GALÍNDEZ, E. J.; ESTECONDO, S. \& CASANAVE, E. B. El bazo de un mamífero con adaptaciones especiales: el «peludo chico» Chaetophractus vellerosus, (Xenarthra, Dasypodidae). Estudio con microscopía de luz y electrónica. Int. J. Morphol., 24(3):339-348, 2006.

RESUMEN: El bazo es un órgano multipotencial y en su microarquitectura se reflejan tanto la filogenia como la adaptación de cada grupo animal e inclusive de cada especie. Los armadillos son un clado antiguo y geográficamente aislado de mamíferos que muestra una mezcla de estructuras ancestrales y modernas. En este trabajo se estudian la microanatomía y citología del bazo del "peludo chico" Chaetophractus vellerosus.

El material se fijó y procesó según las técnicas de rutina de microscopías óptica y electrónica. Los resultados muestran un órgano mediano, del tipo de acumulación, con la típica segregación de pulpas. La pulpa blanca está bien desarrollada pero menos organizada que en otros armadillos. Se observa la presencia de células morfológicamente similares a las foliculares dendríticas y a las interdigitantes, así como agrupamientos de células inmunocompetentes. Estas características apoyan la importancia del órgano en la función inmune.

La pulpa roja es un entramado de espacios vasculares y células libres y fijas. Se reconocen, por primera vez en el Género, la presencia de sinusoides esplénicos. El tejido hemopoyético está presente pero menos desarrollado que en otros Euphractini. Se discute la organización y el tamaño del bazo en contextos filogenético y adaptativo.

PALABRAS CLAVE: Xenarthra; Dasypodidae; Armadillos; Bazo; Chaetophractus vellerosus.

\section{REFERENCES}

Aichele, P.; Zinke, J.; Grode, L.; Schwendener, R.A.; Kaufmann, S. H. E. \& Seiler, P. Macrophages of the splenic marginal zone are essential for trapping of bloodborne particulate antigen but dispensable for induction of specific T-cell responses. J. Immunol., 171:1148-55, 2003.

Bermúdez, P. M.; Polini, N. N. \& Casanave, E. B. A study of platelets in the armadillo chaetophractus villosus (Xenarthra, Dasypodidae). Platelets, 15(5):279-85, 2004.

Blue, J. \& Weiss, L. Species variation in the structure and function of the marginal zone - An electron microscope study of cat spleen. Am. J. Anat. 161:169-87, 1981.

Boggs, D. F.; Frappell, P. B. \& Kilgore, D. L. Ventilatory, cardiovascular and metabolic responses to hypoxia and hypercapnia in the armadillo. Resp. Physiol., 113:1019, 1998.

Boily, P. Individual variation in metabolic traits of wild ninebanded armadillos (Dasypus novemcinctus), and the aerobic capacity for the evolution of endothermy. J. Exp. Biol., 205:3207-14, 2002.
Cabanac, A. J.; Messelt, E. B.; Folkow, L. P. \& Blix, A. S. The structure and blood storing function of the spleen of the hooded seal (Cystophora cristata). J. Zool. London, 248:75-81, 1999.

Carleton, J. P. Cells, Molecules and adaptative radiation in mammals. In: Genoways, H.H. \& Baker, R.J. (eds.) Contributions in Mammalogy: A Memorial Volume Honoring Dr. J. Knox Jones. Museum of Texas Tech. University, Lubbock, 1996. pp. 1-24.

Carlini, A. A. \& Vizcaíno, F. A new record of the armadillo Chaetophractus vellerosus in the Buenos Aires Province of Argentina: possible causes for the disjunct distribution. Studies Neotrop. Fauna Environ., 22:53-6, 1987.

Casanave, E. B. \& Affanni, J. Decrease of body temperature in armadillos experimentally covered by soil. Arch. Physiol. Biochem., 103:29-32, 1995.

Casanave, E. B.; García Samartino, L. \& Affanni, J. Bradycardia in armadillos experimentally covered with soil. Arch. Physiol. Biochem., 103:51-3, 1995. 
Casanave, E. B. \& Polini, N. Comparative study of some haematological parameters of two wild Chaetophractus villosus (Mammalia, Dasypodidae) populations. Comp. Haematol. Int., 9:13-6, 1999.

Casanave, E. B.; Bermúdez, P. M. \& Polini, N. N. Haemostatic mechanisms of the armadillo. Chaetophractus villosus. (Xenarthra, Dasypodidae). Comparative Clinical Pathology, 13(4):171-5, 2005.

Casanave, E. B.; Bermúdez, P. M. \& Polini, N. N. Principal coagulation factors and natural anticoagulants in the armadillo Chaetophractus villosus. (Xenarthra, Dasypodidae). Comparative Clinical Pathology, 14(4):210-6, 2006.

Cheadle, M. A.; Tanhauser, S. M.; Dame, J. B.; Sellon, D. C.; Hines, M.; Ginn, P. E.; Mackay, R. J. \& Greiner, E. C. The nine banded armadillo Dasypus novemcinctus is an intermediate host for Sarcocystis neurona. Int. J. Parasitol., 31:330-5, 2001.

Cisternas, P. A. \& Armati, P. J. Development of the thymus, spleen, lymph nodes and liver in the marsupial Isoodon macrourus (Northern Brown Bandicoot, Peramelidae). Anat. Embryol., 200:433-43, 1999.

Codón, S. M.; Estecondo, S.; Galíndez, E. J. \& Casanave, E.B. Ultrastructure and morphometry of ovarian follicles in the armadillo Chaetophractus villosus (Mammalia, Dasypodidae). Rev. Bras. de Biol., 61:48599, 2001.

Delsuc, F.; Catzeflis, F. M.; Stanhope, M. J. \& Douzery, E. J. P. The evolution of armadillos, anteaters and sloths depicted by nuclear and mitochondrial phylogenies. Implications for the status of the enigmatic fossil Eurotamandua. Proc. R. Soc. Lond., 268:1605-15, 2001.

Díaz, G. B. \& Ojeda, R. A. Libro Rojo de Mamíferos amenazados de Argentina. Sociedad Argentina para el estudio de los Mamíferos, Buenos Aires, 2000.

Estecondo, S.; Casanave, E.B. \& Codón, S.M. Histología de las glándulas pelvianas de Chaetophractus vellerosus (Mammalia, Dasypodidae). Iheringia (sér. Zool.) 83: 85-90, 1997.

Estecondo, S. \& Casanave, E.B. On the presence of pelvian glands in armadillos (Xenarthra, Dasypodidae). Physis, Sec. C., 57:13-7, 1999.

Estecondo, S.; Codón, S. M. \& Casanave, E. B. Scanning electron microscopic study of the dorsal surface of the tongue in Chaetophractus vellerosus (Mammalia, Dasypodidae). Rev. Chil. Anat., 19: 245-52, 2001.

Fernandes, G. F.; Deps, P.; Tomimori-Yamashita, J. \& Camargo, Z. P. IgM and IgG antibody response to Paracoccidioides brasilensis in naturally infected wild armadillos (Dasypus novemcinctus). Medical Micol., 42: 363-8, 2004.

Galíndez, E. J. \& Aggio, M. C. The hemopoietic system. A phylogenetic approach. Histol. Histopathol., 12:823$6,1997$.

Galíndez, E. J.; Aggio, M. C.; Estecondo, S. \& Casanave, E.B. Estructura esplénica de Chaetophractus villosus: Adulto y neonato. Rev. Brasil. Biol., 57:393-401, 1997.

Galíndez, E. J.; Codón, S. M. \& Casanave, E. B. Spleen of Dasypus hybridus (Mammalia, Dasypodidae): A light and electron microscopic study. Anat. Rec., 258:286$91,2000$.

Galíndez, E. J.; Estecondo, S. \& Casanave, E. B. The spleen of Zaedyus pichiy (Mammalia, Dasypodidae): a light and electron microscopic study. Anat. Histol. Embryol. 32:194-9, 2003

Greegor, D. H. Renal capabilities of an Argentine desert armadillo. J. Mammal., 56:626-32, 1975.

Greegor, D. H. Diet of the little hairy armadillo Chaetophractus vellerosus of northwestern Argentina. J. Mammal., 61:331-4, 1980.

Hardman, J. G.; Limbird, L. E. \& Gilman, A. G. Goodman and Gilman's. The pharmacological basis of the therapeutics. $9^{\text {th }}$. Ed. Mc Graw-Hill Interamericana, Mexico, 1996.

Hartwig, H. \& Hartwig, H. G. Structural characteristics of the mammalian spleen indicating storage and release of red blood cells. Aspects of evolutionary and environmental demands. Experientia 41:159-63, 1985.

Hayes, T. G. Structure of the ellipsoid sheath in the spleen of the armadillo (Dasypus novemcinctus). A light and electron microscopic study. J. Morphol., 132: 207-24, 1970.

Maldonado, E.N.; Casanave, E.B. \& Aveldaño, M.I. Major plasma lipids and fatty acids in four HDL mammals. Comp. Biochem. Physiol. A.132:297-303, 2002. 
Polini, N.; Camina, R. \& Casanave, E. B. Morphological and Morphometric study of blood leucocytes from $C$. villosus, Mammalia, Dasypodidae. Comp. Haematol. Int., 9:162-7, 1999.

Scollard, D. M. Endothelial cells and the pathogenesis of lepromatous neuritis. Insights from the armadillo model. Microbes Infection, 2:1835-43, 2000.

Silva Vergara, M. L. \& Martínez, R. Role of the armadillo Dasypus novemcinctus in the epidemiology of parcoccidiomycosis. Mycopathologia, 144:131-3, 1999.

Tanaka, Y. "Intermediate zone" of mammalian spleens: Light and electron microscopic study of three primitive mammalian species (Platypus, Shrew and Mole) with special reference to intrasplenic arteriousvenous communication. Am. J. Anat., 187:313-37, 1990.

Tanaka, Y. Microscopy of the vascular architecture and arteriovenous communications in the spleen of two odontocetes. J. Morphol., 221: 211-33., 1994.

Tanaka, Y.; Eishi, Y. \& Morris, B. Splenic hemopoiesis of the platypus (Ornithorhynchus anatinus): Evidence of primary hemopoiesis in the spleen of a primitive mammal. Am. J. Anat., 181:401-5, 1988.

Weiss, L. New trends in the spleen research: Reticuloendothelial basis of the clearance of blood by the spleen. In: Disorders of the spleen. Pathophysiology and Management (Pochedly, C.; R.H. Sills and A.D. Schwartz, eds.). Marcel Dekker, Inc., New York, 1989. pp. 431-53.

Weiss, L.; Powell, R. \& Schiffman, F. J. Terminating arterial vessels in red pulp of human spleen: a transmission electron microscopic study. Experientia, 41:233-42, 1985.

Weiss, L.P. \& Wislocki, G.B. Seasonal variations in hematopoiesis in the dermal bones of the nine-banded armadillo. Anat. Rec., 126:143-63, 1956.

Zapata, A.G. \& Cooper, E.L. The immune system: Comparative histophysiology. John Wiley and Sons, Chichester, 1990. 334 pp.

Zapata, A. G.; Torroba, M.; Vicente, A.; Varas, A.; Sacedón, R. \& Jiménez, A. The relevance of cell microenvironments for the appearance of lymphohematopoietic tissues in primitive vertebrates. Histol. Histopathol., 10:761-78, 1995.

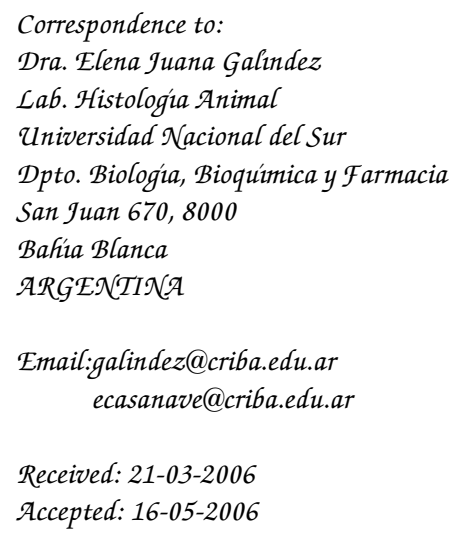

